Check for updates

The BMJ

scook@bmi.com

Cite this as: BMJ 2020;371:m4850

http://dx.doi.org/10.1136/bmi.m4850

Published: 17 December 2020

\title{
Inspirations and silver linings in a pandemic year
}

\section{Sophie Cook head of scholarly comment}

Challenging, unprecedented, turbulent, extraordinary: this year was the toughest that most health professionals have ever known. It's hard to imagine anyone missing 2020 when it's over. In times of darkness, we yearn for inspiration, and this year's Christmas BMJ celebrates and reflects on inspiration in human, artistic, musical, and other forms.

Have world leaders risen to the challenge this year as they struggled to protect the health of their citizens and the economy? Some have excelled while others have faltered. Our Covid-19 Yearbook: World Leaders Edition lets you judge who (if anyone) struck the right balance.

Media doctors make sense of government advice and scientific developments for the public. They step bravely into the limelight to debunk theories and explain the science underpinning decisions. A group of media doctors share how it has felt to lead these conversations during the pandemic. ${ }^{2}$

Role models are important in tough times. We asked a selection of doctors and patients to tell us which fictional doctors from stage, screen, and literature have inspired them and why. Hawkeye Pierce, Miranda Bailey, The Fat Man, and even Dr Dog feature. There is still time to share your medical inspiration with readers on Twitter using the hashtag \#Docspiration.

Perhaps you were inspired to work in medicine by a relative? An observational study from Sweden finds that the proportion of doctors with a physician parent has risen in recent decades, a trend that was not observed in a control group of lawyers. ${ }^{4}$

Audiobooks, exercise, video calls, family time, and supportive teams and colleagues are all rescue remedies and inspirations that have helped doctors and patients through a turbulent year. ${ }^{5}$ Communities have also pulled together. Elliot Hall Medical Centre in Harrow, where staff mobilised patients to support vulnerable people in their community, highlights the power of patient partnership and shows that change for the better is possible even in the hardest of circumstances. ${ }^{6}$

With community in mind, please support our chosen charity this Christmas: the Independent Food Aid Network. This charity has helped independent food banks and other community meal providers throughout a pandemic that has widened inequalities and exacerbated food poverty, increasing demand for food banks. ${ }^{7}$

The festive season will be different this year, but Martin McKee and colleagues can see light at the end of the tunnel, with the arrival of covid-19 vaccines and advances in patient care reducing deaths in those infected. ${ }^{8}$ We must be inspired to build a better future after covid, they say, and health professionals can "offer a compelling vision of how we should reconfigure the world so that it produces and sustains health for all, resilient in the face of future threats."

Looi M-K. Covid 19 yearbook: world leaders edition. BMJ 2020;371:m4728doi: 10.1136/bmj.m4728.

2 Powell J. Meet the medical media faces of the pandemic. BMJ 2020;371:m4707. doi: 10.1136/bmj.m4707 pmid: 33318023

3 Rimmer A. Fictional doctors who inspire. BM/2020;371:m4672 doi: 10.1136/bmj.m4672 pmid: 33262112

4 Polyakova M, Persson P, Hofmann K, Jena AB. Does medicine run in the family-evidence from three generations of physicians in Sweden: retrospective observational study. $B M$ 2020;371:m4453doi: 10.1136/bmj.m4453.

5 Oxtoby K. How we coped with covid-19-and silver linings. BMJ 2020;371:m4335. doi: 10.1136/bmj.m4335 pmid: 33303423

6 Jenner C, Szasz C, Martin J, Herman L, Bekhor J. The hidden army: how a GP-patient volunteer group responded to covid-19. BM/2020;371:m4678. doi: 10.1136/bmi.m4678 pmid: 33323372

7 Feinmann J. The BMJ appeal 2020-21: "Without good nutrition, children's health outcomes worsen, as do their life chances”. BM/2020;371:m4758. doi: 10.1136/bmj.m4758 pmid: 33323373

8 McKee M, van Schalkwyk MCI, Maani N, Galea S. A new year's resolution for health workers. BMJ2020;371:m4602. doi: 10.1136/bmi.m4602 pmid: 33323359 